\title{
Clostridium paradoxum DSM 7308' contains multiple 165 rRNA genes with heterogeneous intervening sequences
}

\author{
Fred A. Rainey, ${ }^{1}$ Naomi L. Ward-Rainey, ${ }^{1}$ Peter H. Janssen, ${ }^{2}$ Hans Hippe ${ }^{1}$ \\ and Erko Stackebrandt ${ }^{1}$
}

\author{
Author for correspondence: Fred A. Rainey. Tel: +495312616 101. Fax: +495312616418 \\ e-mail: rainey@gbf-braunschweig.de
}

\author{
1 DSMZ - Deutsche \\ Sammlung von \\ Mikroorganismen und \\ Zellkulturen $\mathrm{GmbH}$, D- \\ 38124 Braunschweig, \\ Germany \\ 2 Max-Planck-Institut für \\ Terrestrische \\ Mikrobiologie, D-35043 \\ Marburg, Germany
}

\begin{abstract}
Sequence analysis of the cloned 16S rRNA genes of Clostridium paradoxum DSM $7308^{\top}$ revealed the presence of 15 different sequences in variable region I (Escherichia coli positions 73-97) of the 165 rDNA. The majority of the cloned genes contained intervening sequences (IVSs), which varied in length from 120-131 nt, and were present in the DNA obtained from single colonies of $C$. paradoxum. The absence of IVSs in the mature rRNA was demonstrated by Northern hybridization and sequence analysis of the 165 rRNA reverse transcriptase (RT)-PCR product. This finding was supported by the failure of oligonucleotide probes specific for certain IVSs to hybridize to the RT-PCR product obtained from C. paradoxum. Alterations in culture conditions (temperature, pH, salt) or culture age did not lead to expression of RNA containing IVSs, as indicated by the size of RT-PCR products. Hybridization of the restriction-enzyme-digested genomic DNA of $C$. paradoxum with probes derived from the IVSs demonstrated that the 165 rRNA genes containing different IVSs are located at different sites on the chromosome.
\end{abstract}

Keywords: Clostridium paradoxum, $16 \mathrm{~S}$ rRNA/rDNA, multiple operons, operon heterogeneity, intervening sequence

\section{INTRODUCTION}

In recent years, thermophilic bacteria have been the subject of intense investigation due to the potential industrial application of their thermostable enzymes (Kristjansson, 1992). A thermophilic alkaliphilic bacterium was recently described and assigned to the genus Clostridium as Clostridium paradoxum (Li et al., 1993). On the basis of $16 \mathrm{~S}$ rRNA sequence analysis, $C$. paradoxum was shown to belong to the Bacillus/Clostridium subphylum of the Gram-positive line of descent.

The nucleotide sequence of the genes coding for the small and large rRNA subunits are now widely used for the identification and phylogenetic placement of new isolates within the domains Bacteria and Archaea (Olsen et al., 1994; Ludwig \& Schleifer, 1994). In addition, the primary structures of the $16 \mathrm{~S}$ and $23 \mathrm{~S}$ rRNAs have been shown to have enormous potential in the detection of uncultured

Abbreviations: IVS, intervening sequence; RT, reverse transcriptase. The EMBL accession numbers for the sequences reported in this paper are Z69927-Z69942. micro-organisms in environmental samples (Ward et al., 1995). The usefulness of these molecules has stimulated interest in variation in their structure (Gutell et al., 1994). The presence of intervening sequences (IVSs) in rRNA genes could have potential as species- or strain-specific markers. Patel et al. (1992) were first in reporting the presence of an extended stem at variable position I [Escherichia coli positions $73-97$ (Brosius et al., 1978)] in the $16 \mathrm{~S}$ rRNA gene of the thermophilic bacterium Desulfotomaculum australicum; a similar phenomenon was found later in the species Desulfotomaculum thermobenzoicum (Redburn \& Patel, 1993). Subsequent studies demonstrated the presence of large insertions in the $16 \mathrm{~S} r \mathrm{RNA}$ genes of thermophilic clostridia (Rainey et al., 1993), Rbizobium tropici (Willems \& Collins, 1993), Caedibacter caryopbila (Springer et al., 1993), Campylobacter sputorum (van Camp et al., 1993), Campylobacter belveticus (Linton et al., 1994b) and Helicobacter canis (Linton et al., 1994a). Similar IVSs in the $23 \mathrm{~S}$ rRNA gene have been described for Leptospira (Hsu et al., 1990; Ralph \& McClelland, 1993), Salmonella (Winkler, 1979; Smith et al., 1988; Burgin et al., 1990; Hsu et al., 1992), Yersinia (Skurnick \& Toivanen, 1991) and Campylobacter (Konkel et al., 1994; 
Trust et al., 1994) species, and for Coxiella burnetii (Afseth et al., 1995).

The number of rRNA operons in bacterial genomes has been shown to range from 1 to 14 (Young \& Cole, 1993). In most cases, the rRNA genes are linked as a transcription unit in the order 5'-16S-23S-5S-3' (Nomura et al., 1984). Although sequence heterogeneity between $16 \mathrm{~S}$ rDNA operons within the same organism has been shown (Carbon et al., 1979; Mylvaganam \& Dennis, 1992), only a single type of IVS has been described for a given strain.

In the course of an attempt to determine the sequence of the variable region I of $C$. paradoxum, with the view to designing a specific oligonucleotide probe, we observed unusually large PCR amplicons of the 16S rRNA gene of C. paradoxum DSM $7308^{\mathrm{T}}$. Here we present evidence of both multiple 16S rRNA genes, the presence of different sequence composition in insertions at variable region I, and $16 \mathrm{~S}$ rRNA operon heterogeneity.

\section{METHODS}

Bacterial strains and growth conditions. C. paradoxum strain JW-YL-7 (= DSM 7308 ${ }^{\mathrm{T}}$ ) (Li et al., 1993) was grown under a variety of culture conditions for DNA and RNA preparation: temperature $\left(37,55\right.$ or $\left.60^{\circ} \mathrm{C}\right), \mathrm{pH}(7 \cdot 7,9 \cdot 4$ or $10 \cdot 2)$, culture time $(5,18$ or $48 \mathrm{~h})$ and $\mathrm{NaCl}$ concentration $\left(1\right.$ or $\left.45 \mathrm{~g} \mathrm{l}^{-1}\right)$. Except where noted, cultures were grown at $\mathrm{pH} 9.4$, at $55^{\circ} \mathrm{C}$ and with $1 \mathrm{~g} \mathrm{NaCl} \mathrm{l}^{-1}$, and harvested after $18 \mathrm{~h}$. One culture was supplemented with $50 \mathrm{ml}$ soil extract $\mathrm{l}^{-1}$ (Cote \& Gherna, 1994). A bicarbonate-containing, sulfide-reduced mineral medium containing trace elements, selenite/tungstate and vitamins
(Dörner \& Schink, 1990), was prepared in 50 or $200 \mathrm{ml}$ volumes, under a headspace of $\mathrm{N}_{2}$ plus $\mathrm{CO}_{2}(4: 1, \mathrm{v} / \mathrm{v})$ in 125 or $250 \mathrm{ml}$ bottles, respectively. Just prior to inoculation with a stationaryphase culture ( $1 \%$ inoculum, $v / v)$, the medium was supplemented with the appropriate buffer, $10.5 \mathrm{mM}$ nitrilotriacetic acid, $1 \mathrm{~g}$ yeast extract $\mathrm{l}^{-1}$ and $10 \mathrm{mM}$ glucose. The buffers (Sigma) were added from concentrated stock solutions to the following final concentrations: $50 \mathrm{mM}$ HEPPS $/ \mathrm{NaOH}$ for $\mathrm{pH} 7 \cdot 7,25 \mathrm{mM}$ CHES/NaOH plus $25 \mathrm{mM}$ CAPS/ $\mathrm{NaOH}$ for $\mathrm{pH} 9 \cdot 4$, and $50 \mathrm{mM}$ CAPS/ $\mathrm{NaOH}$ for $\mathrm{pH} 10 \cdot 2$. The final $\mathrm{pH}$ of the medium was checked before and after growth, correcting for the growth temperature.

Preparation of single colonies. The agar medium used for the isolation of single colonies of C. paradoxum had the following composition (per l): $5.3 \mathrm{~g} \mathrm{Na}_{2} \mathrm{CO}_{3}, 0.7 \mathrm{~g} \mathrm{Na}_{2} \mathrm{HPO}_{4} .12 \mathrm{H}_{2} \mathrm{O}$, $0.075 \mathrm{~g} \mathrm{KCl}, 20 \mathrm{ml}$ trace element solution (Balch et al., 1979), $5 \mathrm{~g}$ yeast extract, $10 \mathrm{~g}$ tryptone, $0.5 \mathrm{mg}$ resazurin, $15 \mathrm{~g}$ agar (Difco), $4 \mathrm{~g}$ glucose, $0.8 \mathrm{~g}$ L-cysteine. The $\mathrm{pH}$ of the agar medium was adjusted to 10 by adding $10 \mathrm{ml} 2 \mathrm{M} \mathrm{NaOH}$ (autoclaved under nitrogen atmosphere). For colony isolation, a sample taken from a well-sporulated culture was streaked on agar. After anaerobic incubation (Anaerocult bag; Merck) at $55^{\circ} \mathrm{C}$ overnight, well-separated colonies developed. Streaking of single colonies was repeated twice and finally a single colony was transferred into a liquid medium of the same composition.

Preparation of genomic DNA and amplification of the $16 \mathrm{~S}$ rRNA genes. The cells from $10 \mathrm{ml}$ culture were recovered by centrifugation and resuspended in $200 \mu \mathrm{l}$ saline/EDTA buffer [150 mM NaCl, $10 \mathrm{mM} \mathrm{EDTA} \mathrm{(pH} \mathrm{8.0)].} \mathrm{After} \mathrm{the} \mathrm{addition} \mathrm{of}$ $5 \mu$ lysozyme $\left(10 \mathrm{mg} \mathrm{ml}^{-1}\right)$, the solution was incubated at $37^{\circ} \mathrm{C}$ for $30 \mathrm{~min}$. Proteinase $\mathrm{K}\left(5 \mu \mathrm{l}\right.$ of $\left.15 \mathrm{mg} \mathrm{m}^{-1}\right)$ and $10 \mu \mathrm{l}$ SDS $(25 \%, \mathrm{w} / \mathrm{v})$ were added, followed by incubation at $55^{\circ} \mathrm{C}$ for $30 \mathrm{~min}$. DNA was recovered using the Prep-A-Gene kit (Bio-

Table 1. Oligonucleotide primers and probes used in this study

\begin{tabular}{|llc|}
\hline Primer/probe & \multicolumn{1}{c|}{ Sequence (5'-3') } & Target region* \\
\hline 16S rDNA/RNA primers & & \\
$27 \mathrm{f}$ & GAGTTTGATCCTGGCTCAG & $9-27$ \\
$124 \mathrm{f}$ & CACGTGTTACTCACCCGTCC & $105-124$ \\
$343 \mathrm{r}$ & CTGCTGCCTCCCGTA & $343-357$ \\
$357 \mathrm{f}$ & TACGGGAGGCAGCAG & $343-357$ \\
$519 \mathrm{r}$ & G(T/A)ATTACCGCGGC(T/G)GCTG & $519-536$ \\
$530 \mathrm{f}$ & CAGC(C/A)GCCGCGGTAAT(T/A)C & $519-536$ \\
$803 \mathrm{f}$ & ATTAGATACCCTGGTAG & $787-803$ \\
$907 \mathrm{r}$ & CCGTCAATTCATTTGAGTTT & $907-926$ \\
$1114 \mathrm{f}$ & GCAACGAGCGCAACCC & $1099-1114$ \\
$1241 \mathrm{f}$ & TACACACGTGCTACAATG & $1224-1241$ \\
$1385 \mathrm{r}$ & CGGTGTGT(A/G)CAAGGCCC & $1385-1401$ \\
$1406 \mathrm{f}$ & G(A/G)GCCTTG(C/T)ACACACCG & $1385-1401$ \\
$1525 \mathrm{r}$ & AGAAAGGAGGTGATCCAGCC & $1525-1545$ \\
M13 primers & & \\
M13 $(-20)$ & GTAAAACGACGGCCAGT & Cloning vector \\
M13 reverse & GGAAACAGCTATGACCATG & Cloning vector \\
IVS-specific probes & & \\
para1 & ATGTGTTATGCTTTATTTTGC & Within IVS \\
para32 & TTATTCATAATTGGGAAAG & Within IVS \\
para82 & TCAAAGGCTATCAAATTAGC & Within IVS \\
\hline
\end{tabular}

* E. coli numbering (Brosius et al., 1978). 

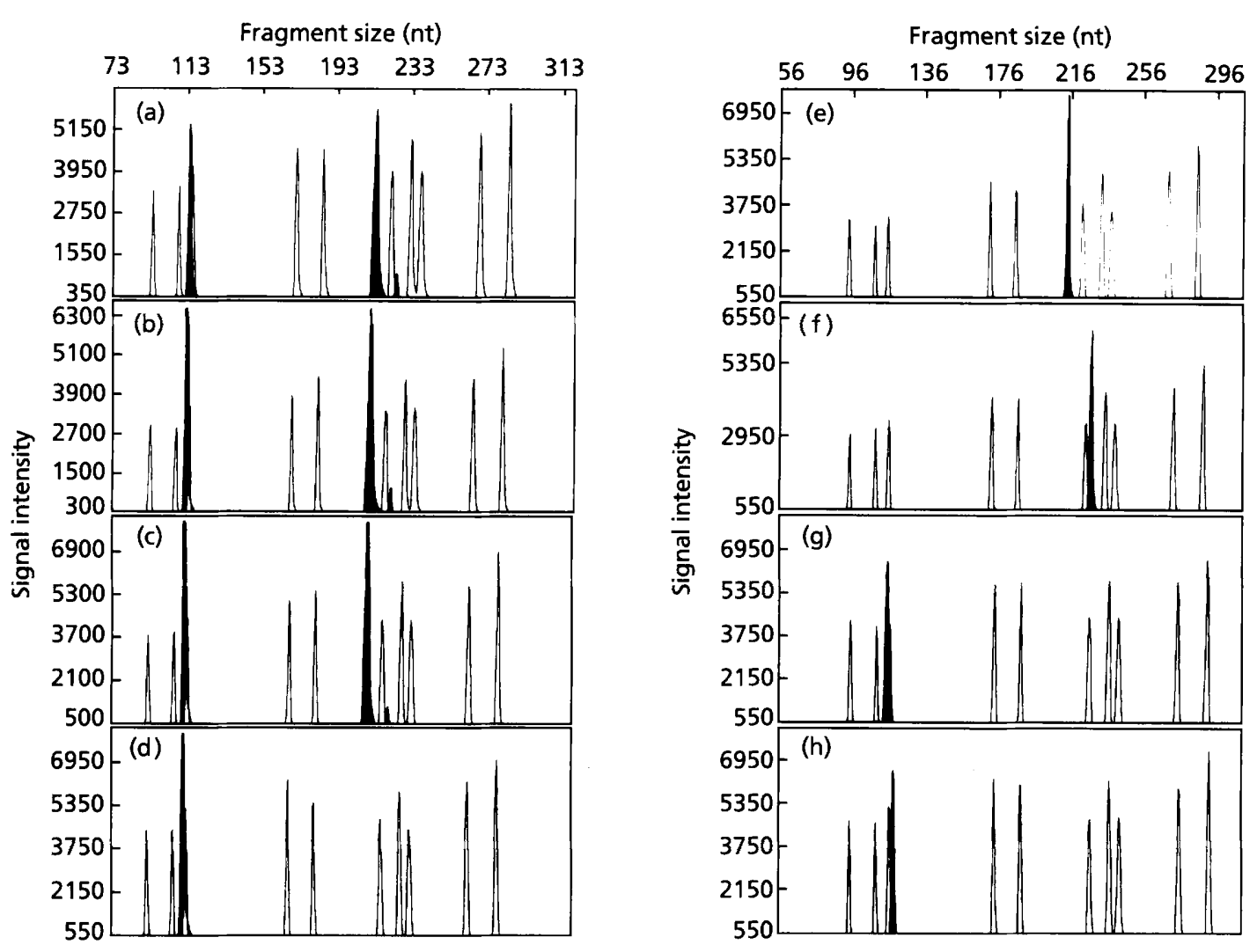

Fig. 1. Fragment size analysis of $P C R$ products. Unless indicated otherwise, $P C R$ products were generated from $C$. paradoxum DNA or RNA. Unfilled peaks represent bands of size standard; filled peaks represent sample bands. PCR template was: (a) genomic DNA (fragment sizes 114, 214, $223 \mathrm{nt}$ ); (b) isolated colony 1 DNA (114, 214, 223 nt); (c) isolated colony 2 DNA $(114,214,223 \mathrm{nt})$; (d) insert of clone para23 DNA (114 nt); (e) insert of clone para27 DNA (214 nt); (f) insert of clone para82 DNA (223 nt); (g) RNA (114 nt); (h) E. coli DNA (118 nt).

Rad). The $16 \mathrm{~S}$ rDNA was amplified by PCR, using the reagents supplied in the TA cloning kit (Invitrogen), 50-100 ng genomic DNA and the primer pair $(0.5 \mu \mathrm{g}$ each) $27 \mathrm{f}$ and $1525 \mathrm{r}$ (Table 1 ). Thermal cycling was performed in a model 480 apparatus (Perkin Elmer). The samples were subjected to an initial denaturing step of $2 \mathrm{~min}$ at $94^{\circ} \mathrm{C}$, after which $2 \mathrm{U}$ Taq polymerase was added to each sample at $90{ }^{\circ} \mathrm{C}$. The thermal profile consisted of 28 cycles of $1 \mathrm{~min}$ at $94^{\circ} \mathrm{C}, 2$ min at $57^{\circ} \mathrm{C}$, and $3 \mathrm{~min}$ at $72{ }^{\circ} \mathrm{C}$. A final extension step of $7 \mathrm{~min}$ at $72{ }^{\circ} \mathrm{C}$ was performed.

Direct cloning of 165 rDNA PCR product. The $16 \mathrm{~S}$ rDNA amplicon was cloned using the TA cloning kit according to the manufacturer's instructions, and transformants containing a complete $16 \mathrm{~S}$ rDNA gene were detected by a rapid disruption method and agarose gel electrophoresis (Sambrook et al., 1989). Cloned inserts were amplified by PCR using the conditions described for $16 \mathrm{~S}$ rDNA above, with the exception that the primers $(0.5 \mu \mathrm{g}$ each) used were M13 $(-20)$ and M13 reverse (Table 1).

Preparation of RNA and amplification of 16S rRNA by reverse transcriptase (RT)-PCR. The total cellular RNA was extracted from the cell pellet obtained from $50 \mathrm{ml}$ culture, using the RNA isolation kit (Stratagene) according to manufacturer's instructions. DNA was completely removed by digestion with $10 \mathrm{U}$ RNase-free DNase (Boehringer Mannheim) at $37^{\circ} \mathrm{C}$ for $1 \mathrm{~h}$. RNA was recovered by extraction with an equal volume of phenol, followed by extraction with an equal volume of chloroform, and precipitation in $0.4 \mathrm{M}$ lithium chloride and 3 vols absolute ethanol. 16S rRNA was amplified by RT-PCR using the RT-PCR kit (Perkin Elmer), according to the manufacturer's instructions, using combinations of the primers $(0.5 \mu \mathrm{g}$ each) $27 \mathrm{f}, 124 \mathrm{r}, 343 \mathrm{r}, 519 \mathrm{r}, 357 \mathrm{f}, 530 \mathrm{f}, 907 \mathrm{r}, 803 \mathrm{f}$ and 1385r (Table 1)

Direct sequencing of PCR products. PCR products were purified using the Prep-A-Gene kit. Sequencing reactions were performed with the Taq DyeDeoxy Terminator Cycle Sequencing Kit (Applied Biosystems) according to the protocol and thermal profile recommended by Applied Biosystems. The sequencing primers used are listed in Table 1. Purified sequence reactions were electrophoresed on a $6 \%(\mathrm{w} / \mathrm{v})$ polyacrylamide sequencing gel for $12 \mathrm{~h}$ using an Applied Biosystems model 373A Automated DNA Sequencer.

Dot blot hybridization of RT-PCR products. Dot blots of RTPCR products were prepared using a BioDot microfiltration apparatus (Bio-Rad), and Hybond-N nylon membrane (Amersham). Oligonucleotide probes were $3^{\prime}$ end-labelled using the end-labelling kit of Boehringer Mannheim, and PCR products were random prime-labelled using the DNA labelling kit of Boehringer Mannheim. Hybridization and chemiluminescent detection was performed as recommended by Boehringer Mannheim.

Southern hybridization of genomic DNA, and Northern hybridization of RNA. Genomic DNA $(5 \mu \mathrm{g})$ was digested with 
$20 \mathrm{U}$ of the restriction endonucleases $A f l \mathrm{II}, B c / \mathrm{I}$ and $E c o \mathrm{RV}$ (New England Biolabs). Restriction digests were electrophoresed in a $1 \%(\mathrm{w} / \mathrm{v})$ agarose gel at $50 \mathrm{~V}$ for $19 \mathrm{~h}$. The DNA was transferred to a Hybond-N nylon membrane. RNA was subjected to agarose gel electrophoresis under standard conditions and Northern blotted onto nylon membrane (Sambrook $e t$ al., 1989). Hybridization with labelled probes, including the IVS-specific probes (Table 1), and chemiluminescent detection were performed as described above.

Fragment size analysis. A labelled partial fragment of the $16 \mathrm{~S}$ rRNA gene was amplified from genomic DNA or cDNA using a FAM-labelled forward oligonucleotide primer (27f) and an unlabelled reverse primer (124r) (Table 1). PCR was performed from genomic DNA or cDNA using the conditions described above. Amplicons were diluted 50-fold and mixed with a loading buffer containing the internal standard GENESCAN2500 (ROX), as recommended by Applied Biosystems. Samples were electrophoresed on a $6 \%(\mathrm{w} / \mathrm{v})$ polyacrylamide gel for $3 \mathrm{~h}$ on an ABI 373A Automated DNA Sequencer. Fragment detection and size analysis were performed using GENESCAN 672 software.

\section{RESULTS}

\section{Cloning and sequencing of the 16S rRNA genes of $C$. paradoxum}

Initial attempts to directly sequence the $5^{\prime}$ end of the $16 \mathrm{~S}$ rDNA PCR product of $C$. paradoxum resulted in unreadable sequence data in the area of variable region I $(E$. coli positions 73-97). This phenomenon suggested the presence of PCR products of differing size and/or sequence. In order to rapidly determine the presence of heterogeneous PCR products, size analysis of the labelled $16 \mathrm{~S}$ rDNA PCR products was performed using GENESCAN. This indicated the presence of fragments of three different sizes, corresponding to 114,214 and $223 \mathrm{nt}$ (Fig. 1a). The same three fragment sizes were observed in the amplification products generated from DNA from each of two single colonies (Fig. 1b, c).

To determine the sequence of the differently sized $16 \mathrm{~S}$ rRNA genes, the complete 16S rRNA gene of $C$. paradoxum was amplified by PCR and cloned in the TA plasmid. Twenty clones were subsequently selected for sequence analysis. Size analysis of labelled fragments of the cloned inserts showed them to be of the three different sizes found previously in analysis of the PCR product generated from genomic DNA (Fig. 1d-f). The sequence of the $5^{\prime}$ end of the 16S rRNA gene of C. paradoxum was determined for each of the 20 clones. Fifteen clones were found to have unique sequences in the $5^{\prime}$ end. The complete sequence of these 15 cloned C. paradoxum $16 \mathrm{~S}$ rRNA genes was determined. The number of bases between positions 73 and 97 (E. coli positions) vatied from 22 to 131.

\section{Determination of the multiple IVSs in variable region I}

Of the 15 deduced C. paradoxum 16S rRNA sequences, 13 differed extensively from the sequence described by $\mathrm{Li}$ et al. (1993) (GenBank accession no. L06838). The differences arose from the fact that these 13 sequences

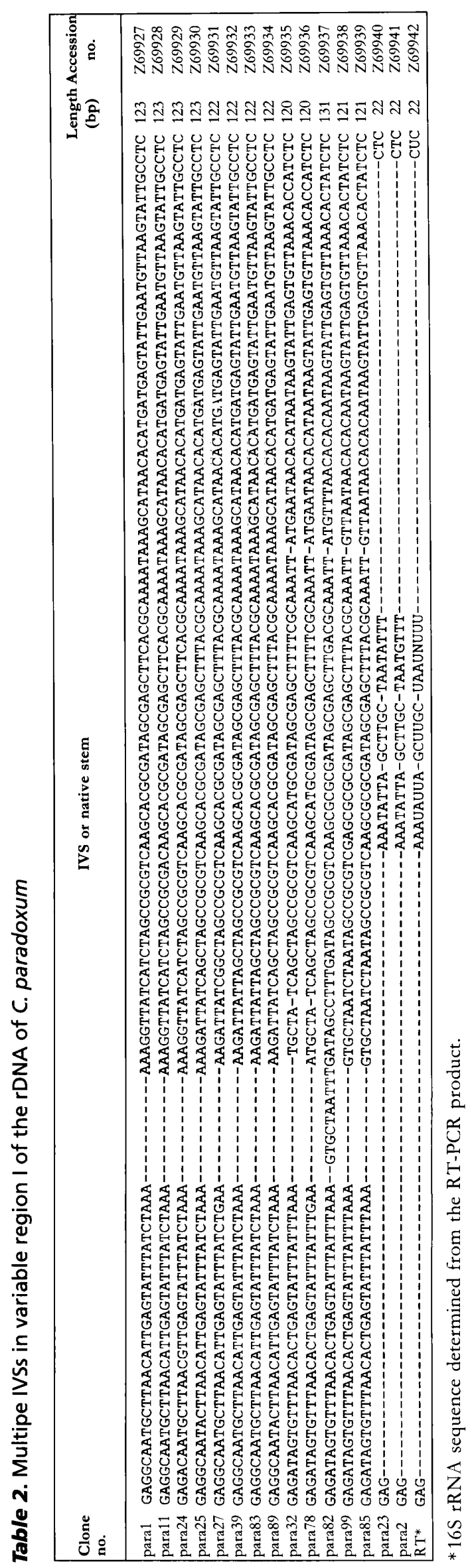


Table 3. Signature nucleotides for the different $C$. paradoxum 16S rDNA clones, outside of variable region I

Variant bases are given in bold.

\begin{tabular}{|c|c|c|c|c|c|c|c|c|c|c|c|c|c|c|c|c|c|}
\hline \multirow[t]{2}{*}{ Posn* } & \multicolumn{15}{|c|}{ para } & \multirow[t]{2}{*}{$\mathbf{R T} \dagger$} & \multirow[t]{2}{*}{ DNA } \\
\hline & 1 & 11 & 24 & 25 & 27 & 39 & 83 & 89 & 32 & 78 & 82 & 99 & 85 & 23 & 2 & & \\
\hline 119 & A & A & A & A & A & A & A & A & A & $A$ & A & A & $A$ & G & A & A & A \\
\hline 232 & G & G & G & G & G & G & G & G & C & $\mathrm{G}$ & G & G & G & G & G & G & G \\
\hline 365 & $\mathrm{~T}$ & $\mathrm{~T}$ & $\mathrm{~T}$ & $\mathrm{~T}$ & $\mathrm{~T}$ & $\mathrm{~T}$ & $\mathrm{C}$ & $\mathrm{T}$ & $\mathrm{T}$ & $\mathrm{T}$ & $\mathrm{T}$ & $\mathrm{T}$ & $\mathrm{T}$ & $\mathrm{T}$ & $\mathrm{T}$ & $\mathrm{U}$ & $\mathrm{T}$ \\
\hline 595 & A & A & A & $\mathrm{A}$ & $\mathrm{A}$ & A & A & A & A & $A$ & G & A & A & A & A & A & A \\
\hline 682 & $\mathbf{G}$ & $\mathbf{G}$ & G & A & A & A & A & A & A & A & A & A & A & $A$ & A & A & $\mathrm{A}$ \\
\hline 699 & C & C & C & C & C & $\mathrm{C}$ & $C$ & C & $\mathbf{T}$ & $\mathrm{T}$ & $\mathrm{C}$ & C & C & C & C & C & $\mathbf{N}$ \\
\hline 721 & A & $A$ & A & A & A & A & A & A & A & $A$ & A & A & A & $A$ & G & A & A \\
\hline 748 & A & A & $A$ & $\mathbf{G}$ & A & A & $\mathrm{A}$ & A & A & $A$ & A & A & A & A & $A$ & A & A \\
\hline 811 & C & C & C & C & $\mathrm{T}$ & C & $\mathrm{C}$ & C & C & C & C & C & C & $C$ & C & C & C \\
\hline 815 & G & A & A & $A$ & A & $A$ & A & A & A & $A$ & A & A & A & A & A & A & A \\
\hline 1002 & $\mathrm{~T}$ & $\mathrm{~T}$ & $\mathrm{~T}$ & $\mathrm{~T}$ & $\mathrm{~T}$ & $\mathrm{~T}$ & $\mathrm{~T}$ & C & $\mathrm{T}$ & $\mathrm{T}$ & $\mathrm{T}$ & $\mathrm{T}$ & $\mathrm{T}$ & $\mathrm{T}$ & $\mathrm{T}$ & $\mathrm{U}$ & $\mathbf{N}$ \\
\hline 1003 & A & $\mathrm{A}$ & A & A & A & A & A & G & A & $A$ & A & $\mathrm{A}$ & $A$ & $A$ & A & A & $\mathbf{N}$ \\
\hline 1005 & G & G & G & G & G & G & G & $\mathbf{A}$ & $\mathbf{A}$ & $\mathbf{A}$ & $\mathbf{A}$ & G & $G$ & $G$ & $\mathbf{A}$ & $\mathbf{N}$ & $\mathbf{N}$ \\
\hline 1022 & $\mathbf{T}$ & $\mathbf{T}$ & $\mathbf{T}$ & C & C & $\mathrm{C}$ & $\mathrm{C}$ & C & C & C & C & $\mathrm{C}$ & C & $\mathrm{C}$ & $\mathrm{C}$ & C & $\mathbf{N}$ \\
\hline 1028 & $\mathrm{C}$ & C & $\mathrm{C}$ & C & $C$ & C & C & C & C & $\mathrm{C}$ & $\mathbf{T}$ & $\mathrm{C}$ & C & C & C & C & $\mathrm{C}$ \\
\hline 1062 & $\mathrm{~T}$ & $\mathrm{~T}$ & C & $\mathrm{T}$ & $\mathrm{T}$ & $\mathrm{T}$ & $\mathrm{T}$ & $\mathrm{T}$ & $\mathrm{T}$ & $\mathrm{T}$ & $\mathrm{T}$ & $\mathrm{T}$ & $\mathrm{T}$ & $\mathrm{T}$ & $\mathrm{T}$ & $\mathrm{L}^{\mathrm{T}}$ & $\mathrm{T}$ \\
\hline 1124 & $\mathrm{G}$ & $G$ & $\mathrm{G}$ & $G$ & G & $\mathrm{G}$ & $G$ & $\mathbf{A}$ & $G$ & G & $\mathrm{G}$ & G & G & $G$ & G & $G$ & $G$ \\
\hline 1180 & A & A & G & A & A & $A$ & A & A & A & $A$ & $\mathrm{~A}$ & A & $\mathrm{A}$ & $A$ & A & A & $\mathrm{A}$ \\
\hline 1265 & C & $C$ & $C$ & $C$ & $C$ & $C$ & $C$ & C & C & C & C & $\mathrm{C}$ & $\mathrm{T}$ & $C$ & C & C & C \\
\hline 1346 & $A$ & $\mathrm{~A}$ & $\mathrm{~A}$ & A & A & $A$ & G & A & A & $A$ & $A$ & A & A & $\mathrm{A}$ & $\mathrm{A}$ & $A$ & $\mathrm{~A}$ \\
\hline 1443 & C & $\mathrm{C}$ & $\mathbf{G}$ & C & C & C & C & C & $C$ & C & C & C & C & $C$ & C & C & C \\
\hline
\end{tabular}

* E. coli numbering (Brosius et al., 1978).

$\dagger 16 \mathrm{~S}$ rRNA sequence determined from the RT-PCR product.

$\ddagger 16 \mathrm{~S}$ rDNA sequence of PCR product prior to cloning.

contain an extra sequence block of 98-109 bp which is not present in the first-described rRNA sequence ( $\mathrm{Li}$ et al., 1993) (Table 2). Sequence differences in other parts of the cloned genes are listed in Table 3.

\section{Sequence determination and fragment size analysis of the 16S rRNA of C. paradoxum}

Sequence determination of the RT-PCR product generated from the RNA of C. paradoxum showed variable region I to consist of $22 \mathrm{bp}$ (Table 2). Fragment size analysis of the RT-PCR product using GENESCAN showed only one fragment of $114 \mathrm{nt}$ (Fig. $1 \mathrm{~g}$ ), in contrast to the rDNA PCR products with three fragments (Fig. $1 \mathrm{a}-\mathrm{c})$. The sequence data obtained for the RT-PCR product had two ambiguities at positions 89 and 1005 ( $E$. coli positions), and subsequent cloning and sequencing of the RT-PCR product revealed the presence of two rRNA copies which differed at these positions. Sequence analysis of the RT-PCR products generated from RNA of cells grown under various conditions (extremes of $\mathrm{pH}$, temperature and salinity) or harvested in different growth phases showed the same sequence as that obtained from cells grown under standard conditions (including the

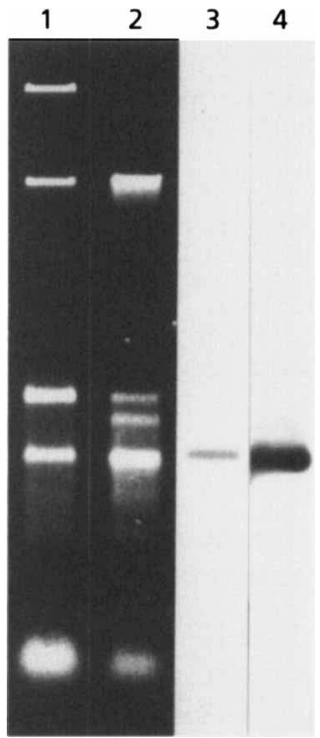

Fig. 2. Agarose gel electrophoresis of RNA (lanes 1 and 2), and Northern hybridization with a DIG-labelled C. paradoxum 165 rDNA probe (lanes 3 and 4). Lanes 1 and 3, E. coli; lanes 2 and 4, C. paradoxum. 
(a)

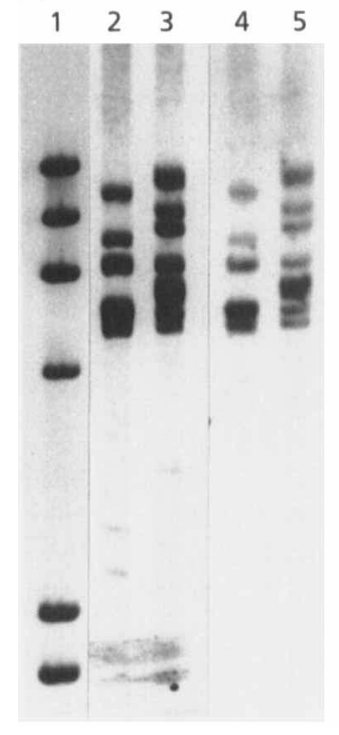

(b)

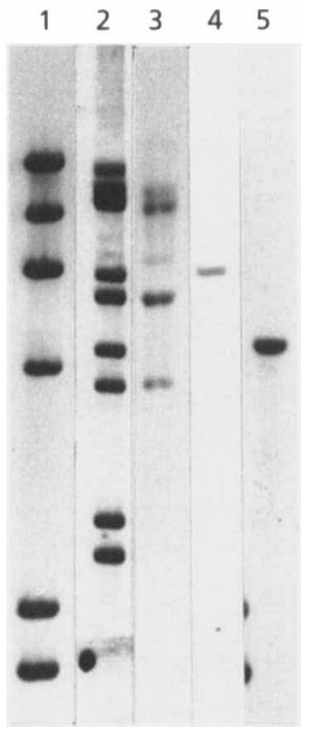

Fig. 3. Hybridization of Southern blots of digested $C$ paradoxum DNA against DIG-labelled probes. (a) Lanes: 1, Boehringer Mannheim DNA molecular mass marker II, DIGlabelled; 2, EcoRV digest hybridized with 16S rDNA probe; 3, $B C / 1$ digest hybridized with 165 rDNA probe; 4, EcoRV digest hybridized with 235 rDNA probe; 5, BC/l digest hybridized with 235 rDNA probe. (b) Lanes: 1, Boehringer Mannheim DNA molecular mass marker II, DIG-labelled; 2-5, AflII digest hybridized with the following probes: 2, 165 rDNA probe; 3, clone para 1 group-specific oligonucleotide probe (representing para 1, 11, 24, 25, 27, 39, 83, 89); 4, clone para32-specific oligonucleotide probe; 5 , clone para 82 -specific oligonucleotide probe.

ambiguity at position 1005). Fragment size analysis of partial RT-PCR products generated from these RNAs showed only one fragment, of the same size as that obtained when the PCR template was RNA from cells grown under standard conditions (data not shown). No signal was obtained after hybridization of dot-blotted RTPCR products with probes specific for the different IVSs (data not shown). Agarose gel electrophoresis of $C$. paradoxum RNA showed three bands corresponding in size to the $16 \mathrm{~S}$ and $23 \mathrm{~S}$ rRNAs as compared to E. coli (Fig. 2). Northern blot analysis using the complete $C$. paradoxum $16 \mathrm{~S}$ rDNA gene as a hybridization probe indicated that only one of the three bands represented a single $16 \mathrm{~S}$ rRNA species.

\section{Localization of different sequence insertions in the genome of $C$. paradoxum}

Hybridization of Southern blots of digested genomic DNA of $C$. paradoxum with oligonucleotide probes specific for some of the insertion types showed that the different insertions are located on different DNA fragments (Fig. 3). Subsequent hybridization with a PCRgenerated 165 rDNA probe, that would hybridize to all clone types, revealed the location of the $16 \mathrm{~S}$ rRNA genes. The pattern obtained from the restriction digest shown in

Fig. 3 suggests that there were at least nine genes. Hybridization with a probe generated from a $23 \mathrm{~S}$ rDNA PCR product of $C$. paradoxum showed that the $23 \mathrm{~S}$ rRNA genes are located on the same restriction fragments as the $16 \mathrm{~S}$ rRNA genes (Fig. 3).

\section{DISCUSSION}

Here we present the first report of heterogeneous IVSs within the $16 \mathrm{~S} r \mathrm{RNA}$ genes of a single strain of a bacterial species. The results obtained from sequencing the cloned $16 \mathrm{~S}$ rDNA of $C$. paradoxum suggest that the number of $16 \mathrm{~S}$ rRNA genes is at least 15 , but may be greater, given the possibility that there is more than one copy of each of the 15 sequence types. The differences between some of the operons is only $1 \mathrm{bp}, \mathrm{e} . \mathrm{g}$. para11 differs from the other clone sequences in having an $\mathrm{A}$ rather than a $\mathrm{T}$ at a given position. It must therefore be considered that such small differences could be the result of PCR-introduced errors. However, the presence of a pairing nucleotide at a distant position in the primary structure of the sequence lends credibility to such differences. Some of these one-base differences are in regions not involved in direct secondary structure pairing and so cannot be verified in this respect.

The presence of additional undetected copies with IVSs of a different size to those reported here is unlikely, given the fact that only three different-sized fragments were detected in the $16 \mathrm{~S}$ rDNA PCR products that were analysed by using GENESCAN software (Fig. $1 \mathrm{a}-\mathrm{c}$ ). It was not possible to determine the exact number of genes by hybridization experiments, as the fragments carrying the $16 \mathrm{~S} r \mathrm{RNA}$ genes are in some cases very close together and difficult to resolve, and some signals obtained after hybridization may represent doublet or even triplet bands (Fig. 3). However, it would appear that there are at least nine different chromosomal locations of the $16 \mathrm{~S}$ rRNA genes. Hybridization with oligonucleotide probes specific for certain IVSs demonstrates that the different IVSs are located at different positions in the chromosome (Fig. 3), although the proximity of the copies has not been determined.

The possibility that the multiple IVSs arise from a culture containing multiple strains was shown to be unlikely by the results of GENESCAN fragment size analysis of single colonies of $C$. paradoxum, in which fragments of the same size as those found in the analysis of the original culture were detected (Fig. 1).

The reported IVSs in 23S rRNA genes are transcribed, and subsequently excised, producing a fragmented mature 23S rRNA molecule (Trust et al., 1994; Konkel et al., 1994; Ralph \& McClelland, 1993; Skurnik \& Toivanen, 1991). The $23 \mathrm{~S}$ rDNAs of the archaea Desulfurococcus mobilis, Stapbylothermus marinus and Pyrobaculum organotrophum have been shown to contain true introns, which are spliced off from the 23S rRNA (Kjems \& Garrett, 1985, 1991; Kjems et al., 1992). The phenomenon has also been reported in the $16 \mathrm{~S}$ rRNA gene of Pyrobaculum aeropbilum (Burggraf et al., 1993). Sequence analysis of 16S rRNA RT-PCR products generated from the RNA of $C$. 
paradoxum revealed that no IVSs are present in the mature $16 \mathrm{~S}$ rRNA which can be amplified by RT-PCR. The $16 \mathrm{~S}$ rRNA sequence determined by Li et al. (1993), using RT sequencing, also contained no IVSs. The RT sequence data alone does not prove that the operons carrying IVSs were not transcribed, since it should not be possible to amplify the rRNA if the IVS-bearing genes were transcribed and the IVSs excised without subsequent religation of the mature fragmented rRNA. The Northern hybridization clearly shows that only one $16 \mathrm{~S}$ rRNA band hybridizes with the $16 \mathrm{~S} \mathrm{rDNA}$ probe. This result indicates that the IVSs are not excised from IVS-bearing transcripts resulting in fragmented $16 \mathrm{~S} r \mathrm{RNA}$. Although not the subject of this study, it is interesting to note that the $23 \mathrm{~S}$ rRNA appears to be fragmented.

The results of this study suggest that only two copies of the $16 \mathrm{~S} \mathrm{rDNA}$ (without large IVSs) are transcribed, and the other copies are silent or redundant. Supporting evidence for this theory is the fact that the sequence of the $16 \mathrm{~S}$ rRNA RT-PCR product contains only two ambiguous base positions corresponding to the heterogeneity of two positions in the transcribed 16S rRNA genes without inserts (para2 and para23 clone types, Table $2)$. If more than these two $16 \mathrm{~S}$ rDNA genes were transcribed, then the variable positions found outside variable region I (Table 3) should result in sequence ambiguity in those positions. In contrast, the sequence data obtained by direct sequencing of the $16 \mathrm{~S}$ rDN A PCR product includes five ambiguous bases (Table 3), corresponding to positions where the different genes have been shown to contain different bases.

Having concluded that the $16 \mathrm{~S}$ rRNA genes bearing IVSs are redundant (not expressed) during normal growth conditions, we attempted to determine whether these genes might be reserved for use under certain environmental conditions. GENESCAN fragment size analysis and sequence analysis of $16 \mathrm{~S}$ rRNA RT-PCR products generated from RNA from cells of C. paradoxum grown under simulated 'extreme' conditions (extremes of temperature, $\mathrm{pH}, \mathrm{NaCl}$ concentration and culture age) clearly demonstrated that these stresses had no influence on the expression of the 16S rRNA genes. This contrasts with the results of similar studies with $E$. coli, in which the levels of expression of certain operons was reported to be affected by culture conditions (Condon et al., 1992).

The apparent dormancy of IVS-bearing $16 \mathrm{~S}$ rRNA genes in $C$. paradoxum invites speculation as to the possible origin of these sequences. Comparison of IVS sequences with the sequence information available in databases such as GenBank has been previously used to determine whether the IVSs are derived from the genomic DNA of other bacteria (Ralph \& McClelland, 1993; Linton et al., 1994a). A similar comparison of the $C$. paradoxum IVSs was performed, but no similarity was found to any sequence contained in GenBank. Another possible IVS source is the genomic DNA of C. paradoxum itself, with the DNA base composition of the IVSs ranging from 33.3 to $38.5 \mathrm{~mol} \% \mathrm{G}+\mathrm{C}$, which is near that of the genomic DNA of C. paradoxum (30 mol\% G + C, Li et al., 1993).
This contrasts with the findings of Konkel et al. (1994) who noted a $22 \cdot 2 \mathrm{~mol} \% \mathrm{G}+\mathrm{C}$ in the $23 \mathrm{~S} \mathrm{rDNA}$ IVS of Campylobacter jejuni, much lower than that reported for the C. jejuni genome $(32.5 \mathrm{~mol} \% \mathrm{G}+\mathrm{C}$; Owen \& Leaper, $1981)$. In this case, the authors suggested an exogenous source for the IVS.

The results of this study demonstrate a large degree of sequence heterogeneity within the $16 \mathrm{~S}$ rRNA genes of $C$. paradoxum. This finding has important implications for the interpretation of data obtained from 16S-rDNA-based taxonomy and microbial ecology studies. These results highlight the need to sequence more than one clone, where cloning is required to obtain readable sequence data. If the sequence of only one cloned gene is analysed and deposited in the database, subsequent comparisons of $16 \mathrm{~S}$ rDNA sequence data from similar strains may lead to erroneous taxonomic conclusions, especially if the highly variable regions were used for the design of oligonucleotide taxon-specific probes.

In microbial ecology studies, the amplified 16S rRNA genes under investigation are often size-selected to avoid cloning nonspecific amplification products. It is possible that larger $16 \mathrm{~S}$ rRNA genes such as those described here may be mistaken for nonspecific products and removed prior to cloning, resulting in loss of this intra-strain heterogeneity and thus some of the microbial diversity. It should be considered that a group of highly related environmental $16 \mathrm{~S}$ rDNA clone sequences such as those that have been found in many environments may represent not a group of separate, phylogenetically highly related strains, but rather the sequence heterogeneity of the $16 \mathrm{~S}$ rDNA contained within one strain. Similarly, the apparent complexity of communities analysed by newly developed methods such as TGGE/DGGE (Muyzer et al., 1993; Muyzer \& de Waal, 1994) could in some situations be attributable to this phenomenon.

The findings of this study, demonstrating the presence of heterogeneity within the $16 \mathrm{~S}$ rRNA genes of a single organism, raise some concerns regarding the use of $16 \mathrm{~S}$ rRNA gene sequences for taxonomic and microbial ecology studies. However, such heterogeneity needs to be further investigated within groups of highly related strains to assess the potential use of this phenomenon as a strain-specific characteristic for strain identification and differentiation.

\section{REFERENCES}

Afseth, G., Mo, Y.-Y. \& Mallavia, L. P. (1995). Characterization of the $23 \mathrm{~S}$ and $5 \mathrm{~S}$ rRNA genes of Coxiella burnetii and identification of an intervening sequence within the $23 \mathrm{~S}$ rRNA gene. J Bacteriol 177, 2946-2949.

Balch, W. E., Fox, G. E., Magrum, R. J. \& Wolfe, R. S. (1979). Methanogens: reevaluation of a unique biological group. Microbiol Rev 43, 260-296.

Brosius, J., Palmer, M. L., Kennedy, J. P. \& Noller, H. P. (1978). Complete nucleotide sequence of a $16 \mathrm{~S}$ ribosomal RNA gene from Escherichia coli. Proc Natl Acad Sci US A 75, 4801-4805.

Burggraf, S., Larsen, N., Woese, C. R. \& Stetter, K. O. (1993). An 
intron within the $16 \mathrm{~S}$ ribosomal RNA gene of the archaeon Pyrobaculum aerophilum. Proc Natl Acad Sci US A 90, 2547-2550.

Burgin, A. B., Parodos, K., Lane, D. J. \& Pace, N. R. (1990). The excision of intervening sequences from Salmonella $23 \mathrm{~S}$ ribosomal RNA. Cell 60, 405-414.

van Camp, G., van de Peer, Y., Nicolai, S., Neefs, J.-M., Vandamme, P. \& de Wachter, R. (1993). Structure of $16 \mathrm{~S}$ and $23 \mathrm{~S}$ ribosomal RNA genes in Campylobacter species: phylogenetic analysis of the genus Campylobacter and presence of internal transcribed spacers. Syst Appl Microbiol 16, 361-368.

Carbon, P., Ehresmann, C., Ehresmann, B. \& Ebel, J.-P. (1979). The complete nucleotide sequence of the ribosomal 16S RNA from Eschericbia coli. Eur J Biochem 100, 399-410.

Condon, C., Philips, J., Fu, Z.-Y., Squires, C. \& Squires, C. L. (1992). Comparison of the expression of the seven ribosomal RNA operons in Eschericbia coli. EMBO J 11, 4175-4185.

Cote, R. J. \& Gherna, R. L. (1994). Nutrition and media. In Metbods for General and Molecular Microbiology, pp. 155-178. Edited by P. Gerhardt, R. G. E. Murray, W. A. Wood \& N. R. Krieg. Washington, DC: American Society for Microbiology.

Dörner, C. \& Schink, B. (1990). Clostridium bomopropionicum sp. nov., a new strict anaerobe growing with 2-, 3-, or 4-hydroxybutyrate. Arch Microbiol 154, 342-348.

Gutell, R. R., Larsen, N. \& Woese, C. R. (1994). Lessons from an evolving rRNA: $16 \mathrm{~S}$ and $23 \mathrm{~S}$ rRNA structures from a comparative perspective. Microbiol Rev 58, 10-26.

Hsu, D., Pan, M.-J., Zee, Y. C. \& LeFebvre, R. B. (1990). Unique ribosome structure of Leptospira interrogans is composed of four rRNA components. J Bacteriol 172, 3478-3480.

Hsu, D., Zee, Y. C., Ingraham, J. \& Shih, L.-M. (1992). Diversity of cleavage patterns of Salmonella 23S rRNA. J Gen Microbiol 138, 199-203.

Kjems, J. \& Garrett, R. A. (1985). An intron in the $23 \mathrm{~S}$ rRNA gene of the archaebacterium Desulfurococcus mobilis. Nature 318, 675-677.

Kjems, J. \& Garrett, R. A. (1991). Ribosomal RNA introns in archaea and evidence for RNA conformational changes associated with splicing. Proc Natl Acad Sci US A 88, 439-443.

Kjems, J., Larsen, N., Dalgaard, J. Z. \& Garrett, R. A. (1992). Phylogenetic relationships amongst the hyperthermophilic archaea determined from partial $23 \mathrm{~S}$ rRNA gene sequences. Syst Appl Microbiol 15, 203-208.

Konkel, M. E., Marconi, R. T., Mead, D. J. \& Cieplak, W., Jr (1994). Identification and characterization of an intervening sequence within the $23 \mathrm{~S}$ ribosomal RNA genes of Campylobacter jejuni. Mol Microbiol 14, 235-241.

Kristjansson, J. K. (1992). Thermopbilic Bacteria. Boca Raton, FL: CRC Press.

Li, Y., Mandelco, L. \& Wiegel, J. (1993). Isolation and characterization of a moderately thermophilic anaerobic alkaliphile, Clostridium paradoxum sp. nov. Int J Syst Bacteriol 43, 450-460.

Linton, D., Clewley, J. P., Burnens, A., Owen, R. J. \& Stanley, J. (1994a). An intervening sequence (IVS) in the 16S rRNA gene of the eubacterium Helicobacter canis. Nucleic Acids Res 22, 1954-1958.

Linton, D., Dewhirst, F. E., Clewley, J. P., Owen, R. J., Burnens, A. P. \& Stanley, J. (1994b). Two types of $16 \mathrm{~S}$ rRNA gene are found in Campylobacter belveticus: analysis, applications and characterization of the intervening sequence found in some strains. Microbiology 140 , 847-855.

Ludwig, W. \& Schleifer, K.-H. (1994). Bacterial phylogeny based on $16 \mathrm{~S}$ and $23 \mathrm{~S}$ rRNA sequence analysis. FEMS Microbiol Rev 15, 155-173.
Muyzer, G. \& de Waal, E. C. (1994). Determination of the genetic diversity of microbial communities using DGGE analysis of PCRamplified $16 \mathrm{~S}$ rDNA. In Structure, Development and Environmental Significance of Microbial Mats, pp. 207-214. NATO ASI Series, vol. G35. Edited by L. J. Stal \& P. Caumette. Berlin: Springer-Verlag. Muyzer, G., de Waal, E. \& Uitterlinde, A. (1993). Profiling of complex microbial populations using denaturing gradient gel electrophoresis analysis of polymerase chain reaction-amplified genes coding for 16S rRNA. Appl Environ Microbiol 59, 695-700.

Mylvaganam, S. \& Dennis, P. P. (1992). Sequence heterogeneity between the two genes encoding $16 \mathrm{~S}$ rRNA from the halophilic archaebacterium Haloarcula marismortui. Gen Soc Am 130, 399-410.

Nomura, M., Gourse, R. \& Baughman, G. (1984). Regulation of the synthesis of ribosomes and ribosomal components. Annu Rev Biochem 53, 75-117.

Olsen, G. J., Woese, C. R. \& Overbeek, R. (1994). The winds of (evolutionary) change: breathing new life into microbiology. J Bacteriol 176, 1-6.

Owen, R. J. \& Leaper, S. (1981). Base composition, size and nucleotide sequence similarities of genome deoxyribonucleic acids from species of the genus Campylobacter. FEMS Microbiol Lett 12, 395-400.

Patel, B. K. C., Love, C. A. \& Stackebrandt, E. (1992). Helix 6 of the $16 \mathrm{~S}$ rRNA of the bacterium Desulfotomaculum australicum exhibits an unusual structure idiosyncrasy. Nucleic Acids Res 20, 5483.

Rainey, F. A., Ward, N. L., Morgan, H. W., Toalster, R. \& Stackebrandt, E. (1993). Phylogenetic analysis of anaerobic thermophilic bacteria: aid for their reclassification. $J$ Bacteriol 175, 4772-4779.

Ralph, D. \& McClelland, M. (1993). Intervening sequence with conserved open reading frame in eubacterial $23 \mathrm{~S}+\mathrm{RNA}$ genes. Proc Natl Acad Sci US A 90, 6864-6868.

Redburn, A. C. \& Patel, B. K. C. (1993). Phylogenetic analysis of Desulfotomaculum thermobenzoicum using polymerase chain reactionamplified 16S rRNA-specific DNA. FEMS Microbiol Lett 113, $81-86$.

Sambrook, J., Fritsch, E. F. \& Maniatis, T. (1989). Molecular Cloning: a Laboratory Manual, 2nd edn. Cold Spring Harbor, NY: Cold Spring Harbor Laboratory.

Skurnik, M. \& Toivanen, P. (1991). Intervening sequences (IVSs) in the $23 \mathrm{~S}$ ribosomal RNA genes of pathogenic Yersinia enterocolitica strains. The IVSs in Y. enterocolitica and Salmonella typhimurium have a common origin. Mol Microbiol 5, 585-593.

Smith, N. H., Crichton, P. B., Old, D. C. \& Higgins, C. F. (1988). Ribosomal-RNA patterns of Escherichia coli, Salmonella typbimurium and related Enterobacteriaceae. J Med Microbiol 25, 223-228.

Springer, N., Ludwig, W., Amann, R., Schmidt, H. J., Goertz, H.-D. \& Schleifer, K.-H. (1993). Occurrence of fragmented 16S rRNA in an obligate bacterial symbiont of Paramecium caudatum. Proc Natl Acad Sci US A 90, 9892-9895.

Trust, T. J., Logan, S. M., Gustafson, C. E., Romaniuk, P. J., Kim, N. W., Chan, V. L., Ragan, M. A., Guerry, P. \& Gutell, R. R. (1994). Phylogenetic and molecular characterization of a $23 \mathrm{~S}$ rRNA gene positions the genus Campylobacter in the epsilon subdivision of the Proteobacteria and shows that the presence of transcribed spacers is common in Campylobacter spp. J Bacteriol 176, 4597-4609.

Ward, N., Rainey, F. A., Goebel, B. \& Stackebrandt, E. (1995). Identifying and culturing the 'unculturables': a challenge for microbiologists. In Microbial Diversity and Ecosystem Function, pp. 89-110, Edited by D. Allsopp, D. L. Hawksworth \& R. R. Colwell. Wallingford: CAB International.

Willems, A. \& Collins, M. D. (1993). Phylogenetic analysis of 
rhizobia and agrobacteria based on $16 \mathrm{~S}$ ribosomal RNA gene sequences. Int J Syst Bacteriol 43, 305-313.

Winkler, M. E. (1979). Ribosomal ribonucleic acid isolated from Salmonella typhimurium: absence of the intact $23 \mathrm{~S}$ species. J Bacteriol 139, 842-849.

Young, M. \& Cole, S. T. (1993). Clostridium. In Bacillus subtilis and
Other Gram-Positive Organisms, pp. 35-52. Edited by A. L. Sonenshein, J. A. Hoch \& R. Losick. Washington, DC: American Society for Microbiology.

Received 23 October 1995; revised 18 March 1996; accepted 28 March 1996. 